Bruno Marques, Alison Baker (2019). Rural Landscape Signatures: the interconnectedness of

place, culture and ecosystems.

Acta Architecturae Naturalis, 5, 37-51.

Submitted: 2019-10-11

Accepted: 2019-11-30

Published: 2019-12-30

ISSN 2228-1320 (print), ISSN 2613-7399 (online)

\title{
Rural Landscape Signatures: the interconnectedness of place, culture and ecosystems
}

\author{
Bruno Marques, Alison Baker \\ Department School of Architecture, Victoria University of Wellington \\ PO Box 600, Wellington 6140, New Zealand \\ E-mail: bruno.marques@vuw.ac.nz \\ Copyright (c) 2019 by Marques, Baker.
}

\section{Abstract}

Aotearoa-New Zealand's legal, ecological and social perspectives are composed of combined Pākehā (NZ European) and Māori identities, values, perspectives and traditions. These two very different cultural perspectives are reflected in the conversations and dialogues occurring with regards to the landscape, and also in the lands forms and features itself. The separation between traditional Māori values and prevailing European developments and design approaches promotes regional landscapes that lack place and a sense of place within the wider Aotearoa-New Zealand context. South Wairarapa, in Aotearoa-New Zealand's lower North Island, presents such a collision; the land bears the imprints of its colonising rural pedigree, and blatantly and unashamedly disregards the undeniable Indigenous Māori connection. This paper explores how landscape architecture can overlay past cultural conversations to restructure and enhance the presence of a defined regional and cultural identity and therefore promote a re-emergence of placed identity. Cultural signatures are written onto the landscape to be read and interpreted, and can be re-written, corrected and modified so to further reflect Indigenous and intrinsic connectedness with one's landscape and its associated processes. The design, management and development of rural regional landscapes can evidence cultural values and landscape heritages while maintaining their obvious need for economic and regional prosperity, and sustainability. The apparent disconnect most modern populations have with their landscape is palpable internationally; the processes and management techniques of old are insufficient. There is a need in Aotearoa-New Zealand for an alternative approach to regional planning and design practices, which evidence our cultural pedigrees. Prominent landscape signatures should be reworked, new ones written, and the old rewritten, to create an inter-relatedness and interconnectedness between humans and ecosystems to protect past places and placements, enhance new ones, and promote the sustainable management and stewardship of the landscape.

\section{Key Words}

Cultural identity, landscape signatures, narratives, identity, riverscapes. 


\section{Introduction}

Landscape Architectural practice insofar seems predominantly entwined with Anglo-American or western constructs: knowledge is scientific, and the world can be constructed into an ordered and manipulable system ${ }^{1}$. Indigenous values regarding landscape tend to be very different; more tradition-oriented and ritualistic, Indigenous values preference deep-rooted connections to ancestry and natural processes; humans are landscape custodians ${ }^{2,3,4,5}$. Mankind and by extension designers, architects, and engineers, seemingly in rejection of such values and beliefs, has so far "turned [its] attention to the means of controlling, directing, organising, and subordinating biological and ecological functions... to curb and eliminate them" ${ }^{6}$. This 'curbing' or 'eliminating' of ecological processes has resulted in large-scale environmental problems - flooding, drought, land degradation, waterway contamination, pollution, habitat destruction, overgrazing ${ }^{7}$. These problems are no more apparent than in our rural landscapes where land is worked and cultivated as a resource and agriculture forms the economic and social backbone of the rural sphere.

The development and sustainable potential of our rural landscapes has been ignored in most aspects of landscape architecture ${ }^{8,9}$. Development of spaces, waterfronts, and riverscapes within the urban realm has been an ever-increasing domain in the profession. The creation of wetland parks, day-lighted streams, designed waterfronts, pocket parks, and the reclaiming of vast open spaces has permeated the discipline of Landscape Architecture; while making the profession more visible, it has also increased the interaction of the public to their landscape, and introduced new or lost ecologies. This type of design seems fairly restricted to the urban realm however; the same attitudes of landscape protection and rejuvenation are not prevalent in the design and preservation of the rural sphere. Instead, the spaces that function to service and supply cities and their residents have been left to decline; their poetic and intrinsic connection to Indigenous groups who were their first custodians has all but diminished.

\footnotetext{
1 Jang, W. S. (2004). A Philosophical Evaluation of Western and Eastern Civilization from a Whiteheadian Perspective. Process Studies, 33(1), 135-148. doi:10.5840/process200433129.

2 Marques, B., Grabasch, G., \& McIntosh, J. (2018). Fostering landscape identity through participatory design with indigenous cultures of Australia and Aotearoa/New Zealand. Space and culture, 1206331218783939.

3 Jakobsson, A. (2009). Experiencing Landscape While Walking: On the Interplay Between Garden Design, Sensory Experience and Medical Spa Philosophy at Ronneby Spa (Unpublished doctoral dissertation). Swedish University of Agricultural Sciences, Alnarp, Sweden.

${ }^{4}$ Henry, E., Pene, H. (2001). Kaupapa Maori: Locating Indigenous Ontology, Epistemology and Methodology in the Academy. Organization, 8(2), 234-242. doi:10.1177/1350508401082009.

${ }^{5}$ Marcus, C., \& Barnes, M. (1999). Healing gardens: Therapeutic benefits and design recommendations. New York, NY: Wiley.

${ }^{6}$ Mumford, L. (1961). The City in History: It's Origins, Transformations, and Prospects. New York: Harcourt, Brace and World. p. 649.

7 Mace, G. M. (2014). Ecology. Whose Conservation? Science, 345(6204), 1558-1560. doi:10.1126cience.1254704 PMID:25258063.

${ }^{8}$ Qviström, M. (2007). Landscapes out of order: studying the inner urban fringe beyond the rural-urban divide. Geografiska Annaler: Series B, Human Geography, 89(3), 269-282.

${ }_{9}$ Makhzoumi, J. M. (2000). Landscape ecology as a foundation for landscape architecture: application in Malta. Landscape and Urban Planning, 50(1-3), 167-177.
} 
Through discussion of the Aotearoa-New Zealand rural landscape and explanation of AotearoaNew Zealand Māori Indigenous values and their influences in our case study region, Wairarapa, we can begin to re-evaluate and study a site as a cultural schema with overlaid cultural conversations. The challenge to designers here is to initiate the design understanding of site-specific Indigenous cultural worldviews and begin paralleling them with modern interventions; the return to initial Indigenous principles through the stewardship and guardianship of the land can combat and alleviate the prominent environmental disregard evident in rural practices and developments. It is necessary to evaluate the constraints and inconsistencies of current landscape practices with particular regard to Indigenous values and other cultural interactions with rural land. Designed intervention can align the aspirations and opportunities of Indigenous value understanding with future rural management and development.

\section{Landscape as Culturally Identifying}

Land is a cultural product; it is a setting for life as well as a space in which cultural achievements, struggles, and interactions take place. Landscape, as expressed by Whiston Spirn (2002; 1998), was the original dwelling, the original text, and the originator of human culture; through it humans shared experiences with ancestors and future generations, their values and beliefs inscribed in the landscape they left as legacy. The development of human culture through landscape manipulations and interactions is obvious - cultures have changed and evolved, so have the lands they inhabit, and the values they associate with their land. This cultural connection is inexplicitly linked to the physical environment through inhabitation, occupation, utilisation, and respect; connection to that landscape informs cultural perception and identification with that environment; their values associated are externalised through their interaction with that environment ${ }^{10}$.

The current western cultural approach to landscape preferences technological advancement, construction, and mechanisation; the land is a tool to be manipulated, and a resource to be procured and bought. Most Indigenous approaches share a commonality of concept - land is literal and metaphysical; humans are because of the land; there is respect for processes and interactions past present and future; everything plays its part in the world system; people belong to the land as custodians and guardians ${ }^{11}$. Although seemingly counter to common western constructs, the Indigenous philosophy has some parallels in other disciplines. Hull, Lam, and Vigo (1994) suggest that place attachments and identifications influence the sense of coherence an individual (or group) feels with their environment, having attributed meaning and significance to places, to others, and to oneself. The development of cultural and individual identity extends to not only the visual, auditory and spatial distinctions between oneself and others, but to connections and interactions between objects, things and material forms, and the very spaces and

\footnotetext{
${ }^{10}$ Baker, A., \& Marques, B. (2017). Out of Place: Rewriting the Signatures of a Landscape. Spaces \& Flows: An International Journal of Urban \& Extra Urban Studies, 8(4).

${ }^{11}$ Mclntosh, J., Marques, B., \& Hatton, W. (2018). Indigenous Cultural Knowledge for Therapeutic Landscape Design. In S. Rosa I, C. Lopes J, R. Ribeiro and A. Mendes (eds.), Handbook of Research of Methods and Tools for Assessing Cultural Landscape Adaptation (pp. 28-52). Parsley, USA: IGI Global.
} 
places in which they are found ${ }^{12,13}$. Identification with place connects otherwise separate individuals through an interaction with a physical environment ${ }^{14}$.

Landscape architects, planners, and designers must understand that the invisible aspects or inferred characteristics and values of a landscape are as essential to meaning and significance as those that are visible and tangible ${ }^{15}$. Cultures input their own identities into a space, and if the space is synergetic with that identity, it becomes theirs. Landscapes are memory; they remember through monuments, changes, layouts, patterns, forms, architectural styles, and inscriptions; a landscape, whether designed purposefully or developing organically is intimately bound up with the lives and values of those who work and exist in and off of $\mathrm{it}^{16}$. Landscapes are physical, social, temporal, sensual and emotive; their cultural values are directly linked to cultural nuances and intrinsic cultural knowledge, and with the land itself.

\section{The Landscape of Aotearoa-New Zealand}

The invasion of European settlers in the early 1800's saw a stage of unprecedented and extraordinary development and environmental change within Aotearoa-New Zealand. Within a short period of time the previous landscape was transformed and shaped into a new type of environment; the fluctuating floodplains, wide valleys, immense plains, and forests of old became a complex array of farm and agricultural land, along with the trappings of western innovation population increases, roadways, railways, townships and mechanization ${ }^{17,18}$. Aotearoa-New Zealand, being one of the last areas on Earth to be colonised is indeed a landscape of two cultures. This remnant of European settlement and colonial culture has continued to permeate AotearoaNew Zealand's development and planning. Aotearoa-New Zealand has established newer rural identities consistent with practices and philosophies of rural colonial England, the precursor to Pākehā culture.

The interaction between Māori and European influence is contentious, and rightly so; the phase of massive cultural and environmental change has been near detrimental to the Māori ways of life; nationwide conflicts between Māori and settler interests arose (and continue) as the AotearoaNew Zealand landscape was stolen and swindled from its original custodians. Māori values evidence an interconnected cultural and ancestral history through the protection and stewardship

12 Petrović, E. K., Marques, B., Perkins, N., \& Marriage, G. (2018). Phenomenology in Spatial Design Disciplines: Could it Offer a Bridge to Sustainability?. In Advancements in the Philosophy of Design (pp. 285316). Springer, Cham.

${ }^{13}$ Proshansky, H., Fabian, A., \& Kaminoff, R. (1983). Place-Identity: Physical World Socialization of the Self. Journal of Environmental Psychology 3, 57-83.

${ }^{14}$ Hull, R. B., Lam, M. \& Vigo, G. (1994). Place Identity: Symbols of Self in the Urban Fabric. Landscape and Urban Planning 28(2-3), 109-120.

${ }^{15}$ Tilley, C. (2006). Identity, Place, Landscape and Heritage. Journal of Material Culture 11(1-2), 7-32.

${ }^{16}$ Tilley, C. (2006). Identity, Place, Landscape and Heritage. Journal of Material Culture 11(1-2), 7-32.

${ }^{17}$ Brooking, T. (2004). The History of New Zealand. Westport, CT: Greenwood Publishing Group.

${ }_{18}$ Meredith, P. (2000, February). Urban Maori as "New Citizens": The Quest for Recognition and Resources. In Revisioning Citizenship in New Zealand conference (pp. 22-24). Hamilton, New Zealand: University of Waikato. 
of the land. Māori are tradition-oriented; their world emphasises ancestral respect, kinship and spiritual connection to the natural world ${ }^{19,20}$. Value often lies in intangible and haptic connections; "landscape is who they are and what shapes their identity" ${ }^{21}$.

Māori tikanga (customs and traditions) imparts an inherent connectedness to the landscape, the stewardship and guardianship of which reflects a cultural wellbeing - the wellbeing (or wellness) of the landscape reflects the wellbeing (or wellness) of the people ${ }^{22}$. Of course, not all Indigenous connections are intangible; the land is first and foremost a source - it supports and allows life. Māori as tangata whenua (people of the land) worked and understood the land as a resource and also as a system that connected them to their ancestors, cultural history, atua (gods), and each other as equal custodians ${ }^{23}$.

Rural planning and landscape architecture in New Zealand particularly at a regional scale seems predominantly and purposefully aligned to consumption, exploitation, and manipulation aligning with changing political and economic sentiments. Value is economic or visual; character and place can be defined by a specified boundary on a plan. Landscapes are designated and managed; they are not seen as a collective and cohesive wholeness of both divine and earthly interacting processes; poetic and haptic qualities are ignored; the essentiality of place and connection to place is avoided in the discussion.

\section{Site: Wairarapa}

At the base of Aotearoa-New Zealand's lower North Island is the Wairarapa region (Figure 1). Once an alluvial plain of lush forest, flourishing wetlands, swamps, and pockets of beech forest, scrubs, and fertile grasslands, the constant fluctuation of Wairarapa's landscape followed the flood and movement habits of Lake Wairarapa, the Ruamāhanga River and its tributaries ${ }^{24}$. Southern migrating Māori assumed mana whenua (customary rights over land) through settlement of the Wairarapa coastline and along its waterways dating back at least 800 years $^{25}$. Later generations

\footnotetext{
${ }^{19}$ Garlick, J., Keane, B., \& Borgfeldt, T. (2010). Te Taiao: Māori and the Natural World. Hong Kong, China: Bateman Publishing.

20 Taua, T. W. (2003). Maori Perspectives on Landscape. Reclaiming Our Heritage, 13-31. Auckland, Takapuna: Environmental Defence Society.

${ }^{21}$ Menzies, D., \& Ruru, J. (2011). Indigenous Peoples' Right to Landscape in Aotearoa New Zealand. In S. Egoz (ed.), The Right to Landscape: Contesting Landscape and Human Rights (pp. 141-152). Surrey: Ashgate.

${ }^{22}$ Hatton, W., Marques, B., \& Mclntosh, J. (2017). Mātauranga Māori and Therapeutic Landscapes. In The IAFOR International Conference on Global Studies 2017: Official Conference Proceedings. Barcelona, Spain: The International Academic Forum. Retrieved from http://papers.iafor.org/wp-content/uploads/conferenceproceedings/CITY/CITY2017_proceedings.pdf.

${ }^{23}$ Harmsworth, G. R., \& Awatere, S. (2013). Indigenous Māori knowledge and perspectives of ecosystems.In J. R. Dymond (Ed.), Ecosystems services in New Zealand - conditions and trends (pp. 274-286). Lincoln, New Zealand: Manaaki Whenua Press.

${ }^{24}$ Hill, R. D. (1963). The Vegetation of the Wairarapa in Mid-Nineteenth Century. Tuatara 11(2), 83-89.

${ }^{25}$ Bagnall, A.G. (1976). Wairarapa: An Historical Excursion. Masterton: Hedley's Bookshop Ltd.
} 
and kin group migrations saw the development of prosperous and thriving iwi ('tribes') which retained separate identities but shared ancestral descent ${ }^{26}$.

Wairarapa Māori regard their landscape as identifying; iwi identity is engrained in the earth, their blood and ancestry in the soil and water. The land was (and still is) an important source of physical and spiritual wellbeing; it is taonga (a highly prized and respected resource) ${ }^{27}$.
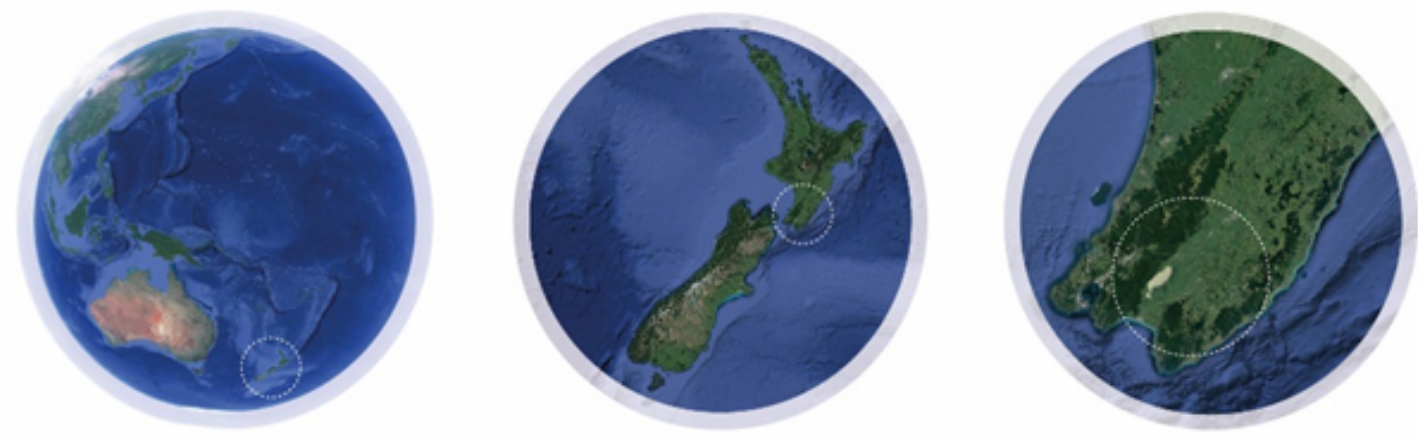

Figure 1: New Zealand and the Wairarapa Site Context.

\section{Wairarapa Māori and Water}

The continual development and modification of Aotearoa-New Zealand's rural agricultural and pastoral areas for the purposes of economic expansion has seen a prominent and near irreversible decline in number and quality of prominent watercourses. Alienation of Māori land and resources through public and private purchases have destroyed or have restricted access to important inland and coastal sites of cultural significance to the tribes ${ }^{28}$. Historically, the Wairarapa Region contained the third largest lake in the North Island of New Zealand and once held some of the country's most significant wetland systems. The combination of extensive agriculture and beef and sheep grazing has resulted in a loss of $37 \%$ of the lake area to industry ${ }^{29}$. Currently the lake is approximately 2.5 meters at its deepest point, more than 3.5 meters shallower than in its recent past. The two main water sources that fuel the lake are the Ruamāhanga and Tuaherenikau Rivers. More than $200 \mathrm{~km}$ of stop-banks (levees) were introduced, altering the flow of rivers and making this region the second highest in the number of stop-banks across New Zealand. The most controversial change in early 1960s was the re-routing of the last segment of the Ruamāhanga River, by disconnecting it from Lake Wairarapa and channelling it in a total length of $4.5 \mathrm{~km}$ straight to Lake Onoke, altering the entire topography of the region (Figure 2). The little remaining open-

\footnotetext{
${ }^{26}$ Waitangi Tribunal Report (2010). The Wairarapa ki Tararua Report. Wellington: Legislation Direct.

${ }^{27}$ Winter, G. (2012). The European Invasion of Wairarapa Moana. In I. F. Grant (ed.), Wairarapa Moana: The Lake and its People (pp. 61-86). Masterton: Wairarapa Archives.

${ }^{28}$ Waitangi Tribunal. (2010). Wairarapa ki Tararua Report: Volume I: The People and the Land (No. WAI863; pp. 1-394). Retrieved from Waitangi Tribunal website: https://waitangitribunal.govt.nz/news/wairarapa-kitararua-report-released-2.

${ }^{29}$ Marques, B., Hunter, A., \& Cole, K. (2016). Bridging the Gap: Indigenous Methods as Necessity to Heal Landscape and Enhance Cultural Identity. In P. Bauer, M. Collender, M. Jakob, L. K. Bonnelame, P. Petschek, D. Siegrist, \& C. Tschumi (Eds.), Conference Proceedings. Series of the Institute for Landscape and Open Space (pp. 297-300). Rapperswil, Switzerland: HSR Hochschule für Technik Rapperswil.
} 
air waterways are irreparably deteriorating; their natural processes and fluctuations are becoming regulated and controlled; their cultural connotations are ignored. Traditional Māori occupation was situated along or close to a prominent freshwater source such as a river, lake, or stream, as was most initial occupations in other countries all over the world - London is located on the River Thames; Cairo and Alexandria on the River Nile; Paris on the River Seine; New Delhi on the River Ganges. The environment provided resources and means, location and direction, and thus became symbols synonymous with place, people and identity.

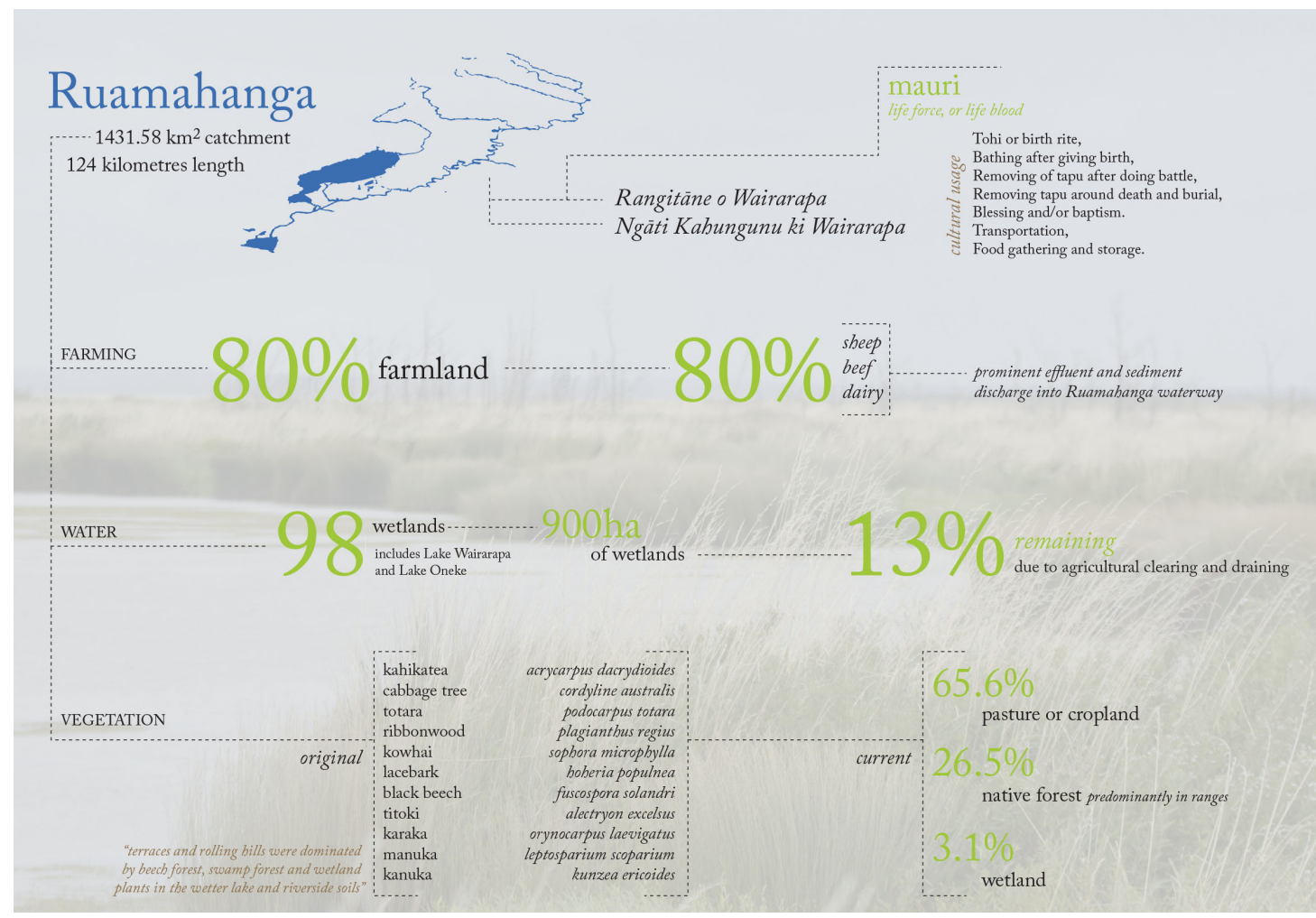

Figure 2: Wairarapa waterways.

Wairarapa waterways and tributaries which once flowed freely across the South Wairarapa plain were no different; the cultural value of the river system is undeniable. District Council documents and other publications discuss and validate the inherent landscape and cultural value of their regional rivers; they are the essential landscape signature, carved and written both into and onto the landscape. Original Māori used the river as a water source, a food source and storage place, for transportation, blessing, and cultural ritual; it provided and enriched the people, and they thus ensured its protection and continuance ${ }^{30}$. European arrival and fast regional development saw the river slowly deteriorate through pollution, sedimentation and increased runoff. Disconnection became normalised, even enjoyed - pastoral run-off flows freely into the waterway seemingly without regulation; parts of the river were privatised and a majority are inaccessible; there is

\footnotetext{
${ }^{30}$ Royal, C. (2011). Cultural Values for Wairarapa Waterways Report. Council Report, Wellington: Prepared by Ohau Plants Ltd for Greater Wellington Regional Council.
} 
minimal ecological buffer. The fluctuations that had for so long defined the Wairarapa region and signalled wealth and fertility were reduced and ignored, and so most disconnected themselves from the river system because they could no longer see it, enjoy it, or understand its connectivity's and systems.

\section{Discussion}

Māori values associated with waterways maintain a consistent theme - centred predominantly around the Māori community reliance on their waterways to nourish wellbeing (mental, spiritual and physical), they form the foundation of Māori cultural identity ${ }^{31}$. Similar themes to Māori are echoed in other Indigenous cultures around the world with relation to waterways, water qualities and flows; the wellbeing of the waterways reflects the wellbeing of the land inhabitants who rely on them; it connects, bonds and protects ways of life ${ }^{32}$. As a landscape signature, the waterways, particularly Wairarapa's Ruamāhanga River, represent wellbeing; they comprise the values of wairua (spiritual wellbeing and eternal sacredness), tinana (physical body wellbeing), hinengaro (mental clarity and learning wellbeing), and whanau (family, community connection). The Ruamāhanga and the ecosystems it supported formed the primary lifeline of the Wairarapa region - all streams and rivers flow into the river and onto the sea through this watercourse ${ }^{33}$.

The conversation of landscape stewardship is central; humans are stewards of their land, and their activity and interaction with it should be reflected in all aspects of landscape management and development, and at all scales. Current legislation attempts to parallel the design and development of land and landscapes with cultural connotations and connections so that they are not separated; the land is a cultural schema as much as it is a manipulable resource and should be treated as such. This, however, is not always practiced; actual development in Aotearoa-New Zealand, particularly of its essential landscape at large scales has seen a predominant domination of Anglo-American values - the land is an asset to be managed, not a system to be protected.

Through utilising the values of kaitiakitanga (understanding of guardianship, the ethic of stewardship), whakapapa (understanding of an eternal inter-relatedness between humans and ecosystems, their intrinsic value), and turangawaewae (understanding of individual as a part and identity of their greater landscape), we can establish a landscape that through the development of prominent cultural and natural signatures allows an inter-relatedness and interconnectedness between humans and ecosystems to be acknowledged and generated (Figure 3). Through immersion and acknowledgement with regards to both intrinsic and economic considerations, through the creation or recognition of Ruamāhanga and Wairarapa narratives and places, and

\footnotetext{
${ }^{31}$ Royal, C. (2011). Cultural Values for Wairarapa Waterways Report. Council Report, Wellington: Prepared by Ohau Plants Ltd for Greater Wellington Regional Council.

32 Mark, G. T., \& Lyons, A. C. (2010). Māori healers' views on well-being: The importance of mind, body, spirit, family and land. Social Science \& Medicine, 70(11), 1756-1764. doi:10.1016/j.socscimed.2010.02.001 PMID:20338680.

33 Royal, C. (2011). Cultural Values for Wairarapa Waterways Report. Council Report, Wellington: Prepared by Ohau Plants Ltd for Greater Wellington Regional Council.
} 


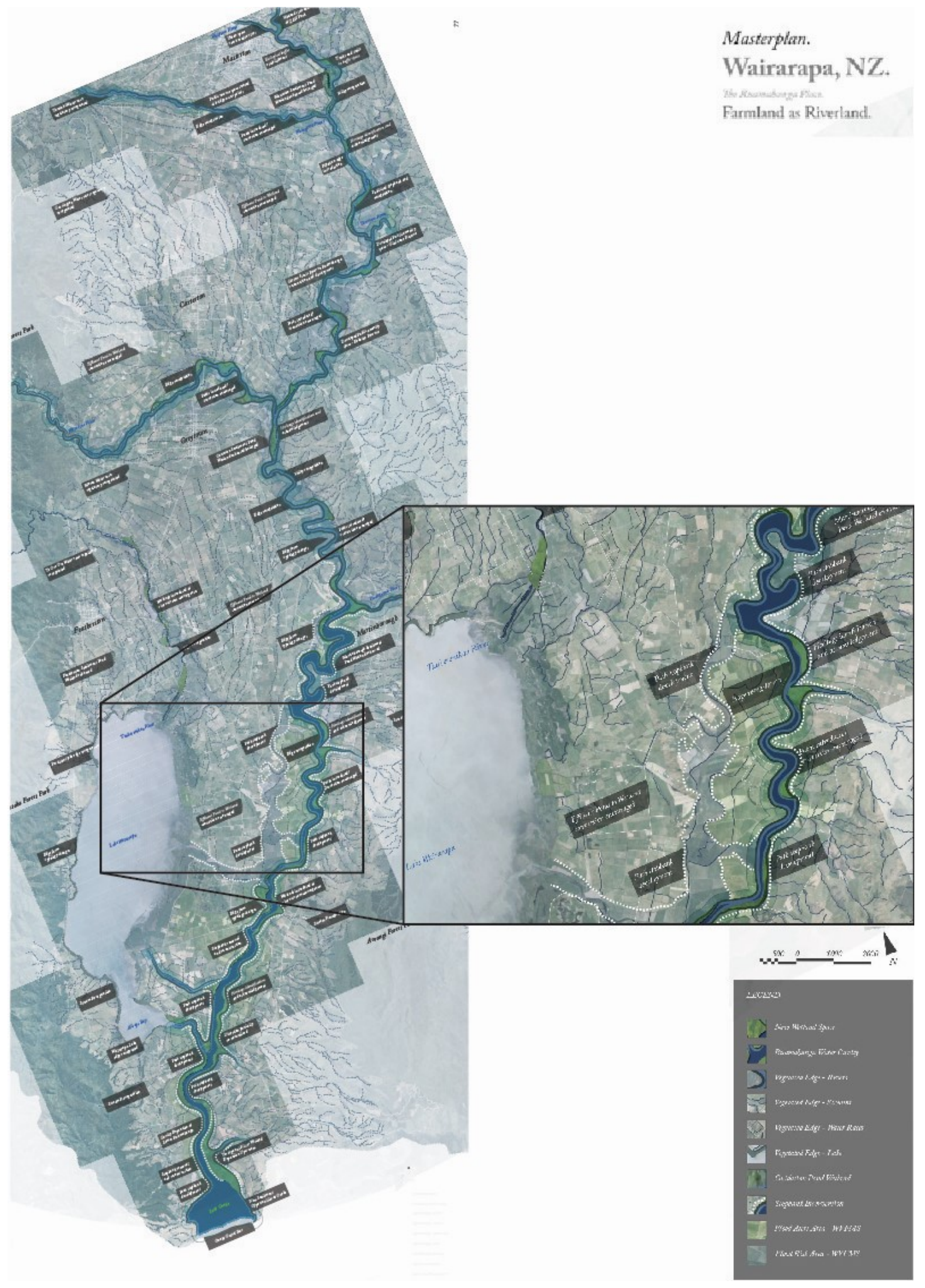

Figure 3: Enhancing Whakapapa at the regional scale. 
through recognition of cultural components and perspectives, we can enhance connections and influence activities, current and future, that reflect an inter-relatedness with the natural systems and processes of one's landscape. Such connections allow the approximation of people to waterways for recreation and food harvesting, which in turn has re-enacted the spiritual notions relating to the ecological health of the river concurrent to the Māori values depicted above and illustrated in Figures 3 and 4. For instance, this new way of thinking has resulted in the Department of Conservation (DOC), a governmental agency, to be responsible in implementing a water conservation order for the lake and to protect māhinga kai (food) and wāhi tapu (sacred sites). At all scales, the regional dynamic can begin to shift and renew to evidence past and present cultural perspectives and heritages to encourage re-placement and the re-emergence of true Wairarapa.

\section{Conclusion}

Regardless of locality or reality, a landscape, whether natural or man-made, physical or imagined, portrays an idea, a perspective, and a philosophy. A designer needs to truly understand the ecological and cultural nuances of a landscape as if it was their own. Specific emphasis must be given to the idea and realities of that place. The identity of a culture or historical event is not always embedded in the designed landscapes, but instead in the spaces and signatures of meaning within that environment. Designers must allow the landscape to be embedded within their own identity and nurture it as a stakeholder. The designer must accept that the place itself has an identity in tandem with those who identify with it; they must understand that an individual's selfperception, and the perception and histories of the place itself have physical, social, temporal, sensual and emotive connotations directly linked to the landscape (Figure 4).

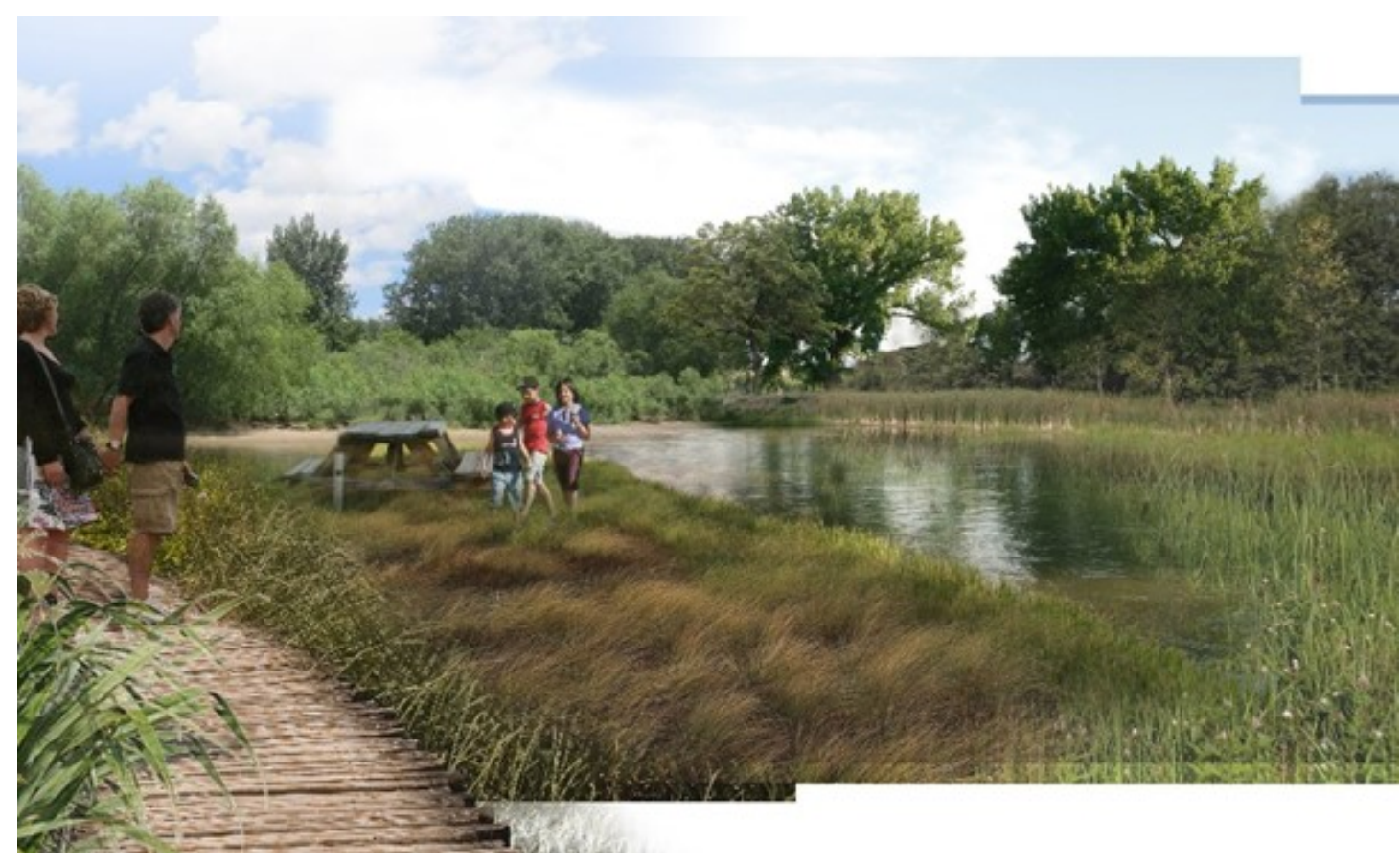

Figure 4: Visualising Turangawaewae at the human scale. 
With the increasing scientific understanding of the detrimental effects, human influence has had on our rural landscapes processes and systems, we as designers in the 21st century are faced with significant challenges because of the landscape interactions of our cultural past. Current regional planning practices and regulations are not enough to protect the ever-worsening landscape practices that have occurred as a result of intensive landscape change and manipulation. The convergence of place, identity and cultures is one possible solution. In Wairarapa, the Ruamāhanga River place and its numerous Indigenous connotations and associations, is a prominent landscape signature and an identifying component of the Wairarapa landscape; it is evidence to the misplacement and discarding of wider river systems within New Zealand's regions, and by extension the world. The consequences of this disregard could be catastrophic with disconnect already palpable. The rural dynamic of extensive individualistic fields and properties is failing in sustainability and management, and consideration for intangible heritage concepts is being all but removed. The true design challenge here exists in balancing the needs of economy, the needs of environmental sustainability, and the values of stewardship to increase social landscape connectivity. The development of the rural landscape arrangement can promote ecological and environmental stewardship through the discussion and integration of Indigenous landscape elements and values (Figure 5).

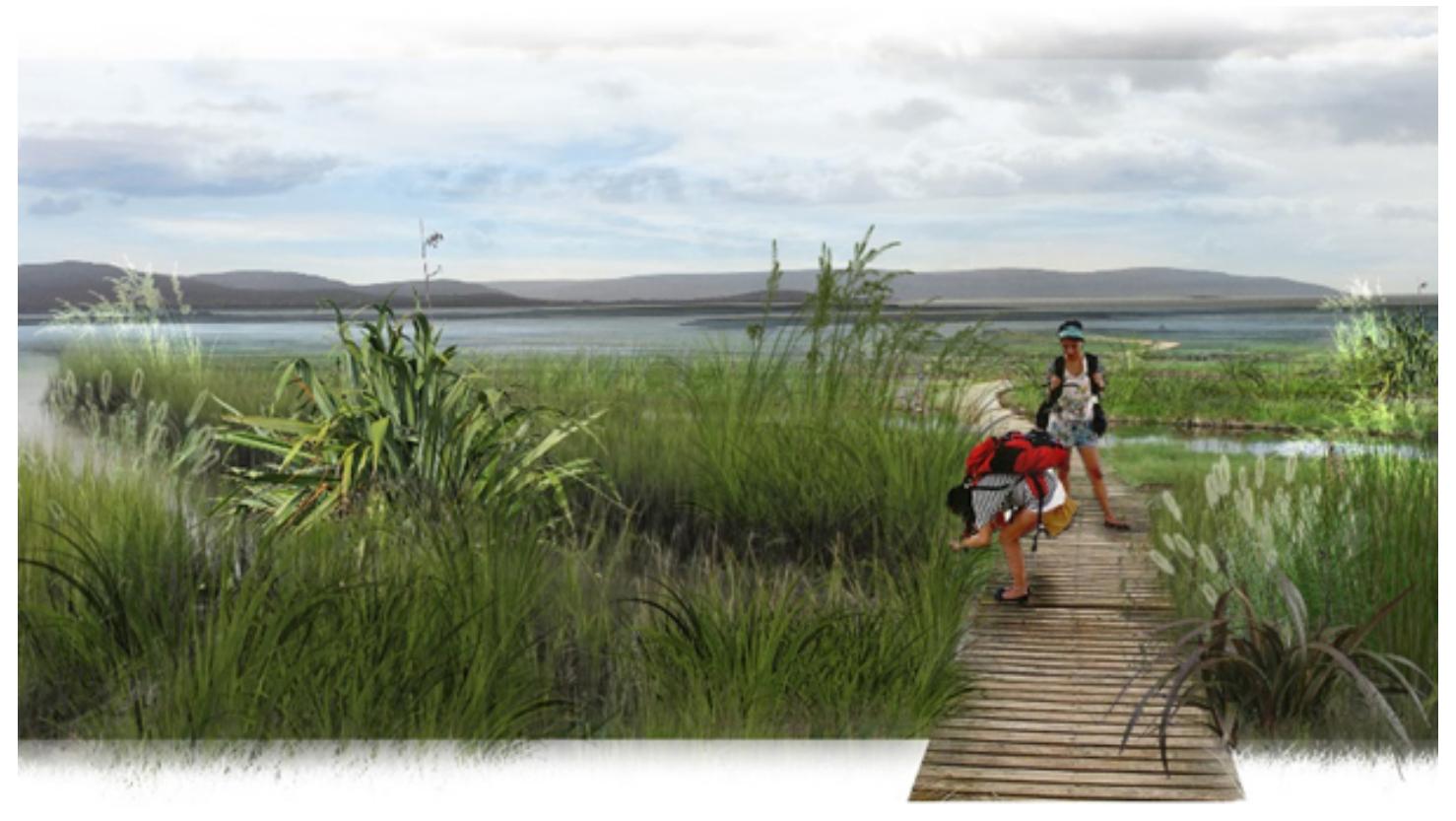

Figure 5: Visualising Kaitiakitanga at the human scale.

Landscape intervention can begin transforming a prominent landscape signature into a regional and social asset wherein future developments can be placed and aligned; new methods of cultural integration can be ignited. Through understanding of identifying cultural placements at various scales of analysis and interaction, we can finally promote the narratives of a region, and propose management methods that align with the perspectives and values of our Indigenous cultures. The promotion of Indigenous perspectives such as stewardship and interconnectedness in designed space can be regionally transformative; it can propose a sustainable future for a region based on 
its heritages and cultural ancestry. Regional and national governance has undermined Māori cultural and ecological values in the Wairarapa. Many waterways, including the Ruamāhanga, are caught in between the economic, cultural and ecological interests, affecting the quality of the water and its surrounding environment. It is the relationship between Māori values and the physical needs of the landscape that supports the argument for a better blue ecology. Mātauranga (knowledge) and Tikanga (customs) Māori equips Māori and non-Māori with a strong link to ecosystems that is holistic and inclusive. This perhaps could even be promoted internationally and utilised in other rural regions where prominent landscape conflict exists, or indeed wherein the current method of planning and protection is not entirely sustainable.

Evidencing how cross-cultural signatures have been written onto the landscape, designers can promote new perspective with regards to waterway management and site-specific landscape signatures. The reading, interpretation, correction and modification of such signatures can encourage landscape stewardship through the interaction with the watercourse, both immediate and tributary. In the case of the Wairarapa Region, the local Māori tribe and the New Zealand Government established the Wairarapa Moana Statutory Board. This board is responsible for the guardianship of the water bodies and resources, including the management of conservation areas, promotion of restoration, protection and enhancement of social, economic, cultural, environmental, spiritual health and wellbeing of the region. Landscape signature design and management in this process can reflect the Indigenous connectedness with one's landscape to allow the formation of new regional identities, identities which highlight the regeneration of perhaps disregarded perspectives and discussions. Through the identification and design of cultural landscape signatures, be they naturalistic, inherent, literal, or monumental, and through the integration of a stewardship approach, we can create new landscapes, which both evidence the cultural pedigree and promise a connected and allied future. Current practices can develop and new plans can be created to generate environmental and landscape stewardship through understanding and interacting with prominent landscape features - landscape features which evidence a connection to the Indigenous cultural past. Nurturing this connection ignites the connectedness of a place and its ecosystems with those who inhabit and utilise it so that the prosperity and wellbeing of the people can be reflected in the prosperity and wellbeing of the landscape, a concept central to not only Māori, but most Indigenous belief.

\section{References}

Bagnall, A.G. (1976). Wairarapa: An Historical Excursion. Masterton: Hedley's Bookshop Ltd.

Baker, A., \& Marques, B. (2017). Out of Place: Rewriting the Signatures of a Landscape. Spaces \& Flows: An International Journal of Urban \& Extra Urban Studies, 8(4).

Brooking, T. (2004). The History of New Zealand. Westport, CT: Greenwood Publishing Group.

Garlick, J., Keane, B., \& Borgfeldt, T. (2010). Te Taiao: Māori and the Natural World. Hong Kong, China: Bateman Publishing. 
Harmsworth, G. R., \& Awatere, S. (2013). Indigenous Māori knowledge and perspectives of ecosystems.In J. R. Dymond (Ed.), Ecosystems services in New Zealand - conditions and trends (pp. 274-286). Lincoln, New Zealand: Manaaki Whenua Press.

Hatton, W., Marques, B., \& McIntosh, J. (2017). Mātauranga Māori and Therapeutic Landscapes. In The IAFOR International Conference on Global Studies 2017: Official Conference Proceedings. Barcelona, Spain: The International Academic Forum. Retrieved from http://papers.iafor.org/wp-content/uploads/conferenceproceedings/CITY/CITY2017_proceedings.pdf.

Henry, E., \& Pene, H. (2001). Kaupapa Maori: Locating Indigenous Ontology, Epistemology and Methodology in the Academy. Organization, 8(2), 234-242. doi:10.1177/1350508401082009

Hill, R. D. (1963). The Vegetation of the Wairarapa in Mid-Nineteenth Century. Tuatara 11(2), 8389.

Hull, R. B., Lam, M. \& Vigo, G. (1994). Place Identity: Symbols of Self in the Urban Fabric. Landscape and Urban Planning 28(2-3), 109-120.

Jakobsson, A. (2009). Experiencing Landscape While Walking: On the Interplay Between Garden Design, Sensory Experience and Medical Spa Philosophy at Ronneby Spa (Unpublished doctoral dissertation). Swedish University of Agricultural Sciences, Alnarp, Sweden.

Jang, W. S. (2004). A Philosophical Evaluation of Western and Eastern Civilization from a Whiteheadian Perspective. Process Studies, 33(1), 135-148. doi:10.5840/process200433129

Mace, G. M. (2014). Ecology. Whose Conservation? Science, 345(6204), 1558-1560. doi:10.1126cience.1254704 PMID:25258063

Makhzoumi, J. M. (2000). Landscape ecology as a foundation for landscape architecture: application in Malta. Landscape and Urban Planning, 50(1-3), 167-177.

Marcus, C., \& Barnes, M. (1999). Healing gardens: Therapeutic benefits and design recommendations. New York, NY: Wiley.

Mark, G. T., \& Lyons, A. C. (2010). Māori healers' views on well-being: The importance of mind, body, spirit, family and land. Social Science \& Medicine, 70(11), 1756-1764. doi:10.1016/j.socscimed.2010.02.001 PMID:20338680

Marques, B., Grabasch, G., \& McIntosh, J. (2018). Fostering landscape identity through participatory design with indigenous cultures of Australia and Aotearoa/New Zealand. Space and culture, 1206331218783939.

Marques, B., Hunter, A., \& Cole, K. (2016). Bridging the Gap: Indigenous Methods as Necessity to Heal Landscape and Enhance Cultural Identity. In P. Bauer, M. Collender, M. Jakob, L. K. 
Bonnelame, P. Petschek, D. Siegrist, \& C. Tschumi (Eds.), Conference Proceedings. Series of the Institute for Landscape and Open Space (pp. 297-300). Rapperswil, Switzerland: HSR Hochschule für Technik Rapperswil.

McIntosh, J., Marques, B., \& Hatton, W. (2018). Indigenous Cultural Knowledge for Therapeutic Landscape Design. In S. Rosa I, C. Lopes J, R. Ribeiro and A. Mendes (eds.), Handbook of Research of Methods and Tools for Assessing Cultural Landscape Adaptation (pp. 28-52). Parsley, USA: IGI Global.

Menzies, D., \& Ruru, J. (2011). Indigenous Peoples' Right to Landscape in Aotearoa New Zealand. In S. Egoz (ed.), The Right to Landscape: Contesting Landscape and Human Rights (pp. 141-152). Surrey: Ashgate.

Meredith, P. (2000, February). Urban Maori as "New Citizens": The Quest for Recognition and Resources. In Revisioning Citizenship in New Zealand conference (pp. 22-24). Hamilton, New Zealand: University of Waikato.

Mumford, L. (1961). The City in History: It's Origins, Transformations, and Prospects. New York: Harcourt, Brace and World.

Petrović, E. K., Marques, B., Perkins, N., \& Marriage, G. (2018). Phenomenology in Spatial Design Disciplines: Could it Offer a Bridge to Sustainability?. In Advancements in the Philosophy of Design (pp. 285-316). Springer, Cham.

Proshansky, H., Fabian, A., \& Kaminoff, R. (1983). Place-Identity: Physical World Socialization of the Self. Journal of Environmental Psychology 3, 57-83.

Qviström, M. (2007). Landscapes out of order: studying the inner urban fringe beyond the ruralurban divide. Geografiska Annaler: Series B, Human Geography, 89(3), 269-282.

Royal, C. (2011). Cultural Values for Wairarapa Waterways Report. Council Report, Wellington: Prepared by Ohau Plants Ltd for Greater Wellington Regional Council.

Spirn, A. W (2002). 'Language of Landscape'. In S. Swaffield (ed.), Theory in Landscape Architecture: A Reader (pp. 125-130). Philadelphia: University of Pennsylvania Press.

Spirn, A. W. (1998). The Language of Landscape. USA: Thomson-Shore, Inc.

Taua, T. W. (2003). Maori Perspectives on Landscape. Reclaiming Our Heritage, 13-31. Auckland, Takapuna: Environmental Defence Society.

Waitangi Tribunal Report (2010). The Wairarapa ki Tararua Report. Wellington: Legislation Direct.

Tilley, C. (2006). Identity, Place, Landscape and Heritage. Journal of Material Culture 11(1-2), 7-32.

Waitangi Tribunal. (2010). Wairarapa ki Tararua Report: Volume I: The People and the Land (No. WAl863; pp. 1-394). Retrieved from Waitangi Tribunal website: https://waitangitribunal.govt.nz/news/wairarapa-ki-tararua-report-released-2 
Winter, G. (2012). The European Invasion of Wairarapa Moana. In I. F. Grant (ed.), Wairarapa Moana: The Lake and its People (pp. 61-86). Masterton: Wairarapa Archives. 